\title{
MENGGAGAS SUATU KAWASAN INDUSTRI
}

\author{
Sutanto \\ Program Studi Diploma III Teknik Sipil \\ Fakultas Teknik Universitas Diponegoro
}

\begin{abstract}
Sutanto, in this paper explain that industrial area is the area where the concentration of industrial activities whose existence the ideal should be integrated with other areas such as residential, office, education, economic activity and other agricultural green belt - the other. This industrial area should be equipped with infrastructure and other support facilities so as to serve the upstream to downstream processes. The necessary infrastructure and facilities such as office managers, environmental facilities, the network - a network of roads, electricity, telecommunications, sewage, water, fire and reforestation. For industrial buildings must meet the requirements of building height, building area coefficient referring to the City Master Plan.
\end{abstract}

Keywords: city master plan

\section{PENDAHULUAN}

Suatu Kota diidealisasikan merupakan perpaduan antara beberapa kawasan diantaranya Pemukiman, Perkantoran, Pendidikan, Kegiatan Ekonomi, Industri, Pertanian dengan sabuk hijau dll., untuk mewujudkan hal itu dibutuhkan bukan sekedar mengenai penataan kawasan, namun juga infra struktur dan supra strukturnya termasuk para penentu kebijakan. Kawasan industri adalah kawasan tempat pemusatan kegiatan industri pengolahan yang dilengkapi dengan prasarana dan sarana serta fasilitas penunjang lainnya yang semuanya mengacu pada rencana induk kota.

\section{SARANA DAN PRASARANA KAWASAN INDUSTRI}

Pada prinsipnya, suatu kawasan industri harus direncanakan yang ideal dengan kelengkapan penunjangnya. Kelengkapan sarana dan prasarana kawasan industri sangat membantu untuk proses kegiatan industri agar dapat berlangsung dengan baik.Sarana dan prasarana industri terdiri dari :

- Kantor Pengelola.

Merupakan wadah pusat aktivitas badan atas lembaga yang mengelola kawasan industri selain berfungsi sebagai tata usaha dan administrasi perkantoran, disini adalah tempat kebijakan pengelola digariskan, ditempat ini pula dilakukan koordinasi, pengawasan dan pengendalian. Pada lokasi ini dapat diperluas fungsi dan dikembangkan dengan fasilitas kantor sewa bagi badan - badan yang terkait dengan kawasan industri seperti misal : Bank, Asuransi, Jasa angkutan dll.

- Fasilitas Lingkungan.

Fasilitas lingkungan dengan penggunaannya dapat dipakai bersama; baik secara internal pihak - pihak yang berhubungan langsung dengan kawasan industri maupun secara ekternal bagi lingkungan sekitar kawasan industri. Fasilitas yang ada dapat berupa gedung serba guna, olah raga, kesehatan, bimbingan dan latihan tenaga kerja, tempat Ibadah, keamanan, pemadam kebakaran dll.

- Jaringan Jalan.

Pada jaringan jalan, khususnya intra kawasan industri harus direncanakan mengikuti pola tata jaringan ruang kawasan industrinya. Dengan demikian diharapkan peran pelayananya sesuai kebutuhan dan aksesibilitasnya mudah. Rencana pola jaringan jalan harus memperhitungkan keadaan geografis dan topografik yang ada. Kriteria teknis geometris jalan tetap mengacu pada standard perencanaan geometri jalan raya yang berlaku di Indonesia.

- Jaringan Listrik.

Jumlah daya dan karakteristik penggunaan listrik tidak sama bagi setiap pabrik maupun fasilitas lainnya, hal ini tergantung dari aktifitas dan jenis industri. Ada beberapa alternatif untuk memenuhi suply daya listrik, yaitu :

o Kebutuhan sumber daya listrik dipenuhi secara utama oleh PLN, dengan disediakan generator cadangan apabila terjadi gangguan PLN.

o Kebutuhan daya listrik dipisah antara aktifitas perkantoran dan proses produksi masing - masing apakah disediakan PLN atau generator tersendiri.

- Jaringan Telekomunikasi.

Kebutuhan fasilitas telekomunikasi baik jumlahnya, sistemnya maupun prasyaratan lainnya dipenuhi oleh PT. Telkom ataupun layanan Jasa Telekomunikasi yang lain.

- Jaringan Air Bersih.

Sumber air bersih dapat diperoleh dari PDAM, kekurangannya dari sumber lain dengan tetap mempertimbangkan stabilitas sumber daya air, Jaringan harus memadahi dengan pemasangan instalasi pipa dalam tanah dengan dimensi dan 
kekuatan bahan yang memadai. Pendistribusian kepada konsumen melalui bak reservoir, dapat juga dengan sistem gravitasi dan apabila perlu dengan sistem pompa.

- Jaringan Air Kotor.

Jaringan yang dimaksud adalah jaringan untuk air kotor domestik yang non proses industri dan air hujan memakai jaringan sistem terbuka yang dialirkan ketempat peresapan pada setiap lahan, serta sebagian dialirkan kesungai / saluran induk melalui treatment ringan.

- Jaringan Air Limbah.

Merupakan suatu sistem jaringan tersendiri dan terpisah dari jaringan air kotor, jaringan ini berupa pipa dalam tanah yang menghubungkan pabrik dengan waste water treatment plant yang diteruskan kekolam pembuangan / fishpond yang berfungsi sebagai kolam pemantauan. Disini peranan IPAL sangat diharuskan.

- Jaringan Pemadam Kebakaran.

Sistem jaringan pemadam kebakaran memakai pipa air di dalam tanah dengan persyaratan teknis tertentu, di mana pada jarak tertentu sekurang - kurangnya $120 \mathrm{~m}$ diberi hydrant yang ditempatkan pada tepi jalan yang ada. Cara yang dikombinasikan dengan disediakannya mobil pemadam kebakaran dengan alat penyemprot minimal 2 (dua) unit untuk mobil berkapasitas 6.000 liter. Secara mikro ada keharusan bagi setiap pabrik / kantor untuk meyediakan sendiri alat pemadam kebakaran.

- Penghijauan

Fungsi penghijauan disini adalah :

o Menjaga kelestarian ekosistem

o Untuk menyegarkan lingkungan

o Sebagai paru - paru lingkungan industri

o Meningkatkan estetika lingkungan

Bentuk penghijauan dapat merupakan :

o Sabuk hijau

o Taman lingkungan

o Peneduh

o Tanaman

\section{BANGUNAN DAN PERSYARATAN}

Fungsi bangunan sebagai sarana kegiatan industri harus diatur sedemikian rupa sehingga tata ruang, analisa tapak, pencahayaan dapat mendukung efisiensi dan produktifitas optimal. Dalam kawasan industri perlu diatur hal - hal yang berkaitan dengan bangunan, antara lain :

- Tinggi bangunan yang diperkenankan adalah maksimal menyesuaikan dengan tolok ukur yang ada pada kawasan industri yang tertuang dalam Rencana Induk Kota.

- Floor Area Ratio (FAR) atau Koefisien Luas Bangunan (KLB) harus menyesuaikan dengan peraturan tentang hal itu, seperti petunjuk yang ada pada RBWK.

- Building Coverage (BC) atau Koefisien Dasar Bangunan (KDB) yang diperkenankan maksimal 60\% dengan pertimbangan masih ada ruang terbuka untuk setiap kaplingnya.

- Jarak antar bangunan untuk sisi belakang dan samping adalah minimal separo (1/2) tinggi kumulatif bangunan.

- Baris sepadan bangunan adalah sama dengan lebar jalan di depannya.

- Setiap kapling harus menyediakan sumur peresapan air.

\section{PENUTUP}

Penyediaan fasilitas kawasan Industri berdampak luas pada perkembangan kota . Dengan menarik investor untuk menanamkan modalnya serta mengembangkan industrinya; akan berpengaruh secara signifikan untuk meningkatkan pendapatan daerah, menaikkan devisa, memanfaatkan sumber daya alam dan membuka lapangan kerja baru.

Penanganan kawasan industri perlu dilakukan secara hati - hati dan terpadu baik menyangkut peraturan - peraturan, teknis perencanaan dan lain - lain agar kemudian hari dapat tumbuh dan berkembang secara maksimal dengan meminimalisasikan dampak negatipnya.

\section{DAFTAR PUSTAKA}

1. Perdana Gintings, 1995, Mencegah Dan Mengendalikan Pencemaran Industri, Jakarta: PT Pustika Sinar Harapan.

2. Wignjosoebroto Sritomo, 1991, Tata Letak Pabrik dan Pemindahan Bahan, Jakarta: Guna Widya.

3. Hariadi,B. Setiawan, 1995, Arsitektur Lingkungan dan Perilaku, Yogyakarta: Direktorat Jenderal Pendidikan Tinggi Departemen Pendidikan dan Kebudayaan RI.

4. Suroto, 1994, Strategi Pembangunan dan Perencanaan Kesempatan Kerja, Yogyakarta: Gajah Mada University Press.

5. Frick Heinz,Ir, 1988, Arsitektur dan Lingkungan, Yogyakarta: Kanisius. 